\title{
'Club versus country' in rugby union: tensions in an exceptional New Zealand system
}

\author{
Camilla Obel \\ School of Sociology and Anthropology, University of Canterbury, Christchurch, New Zealand
}

In contrast to the global reach and popularity of the association game, rugby union enjoys the position of being the national sport of New Zealand. This position is sustained by an exceptional model of governance with central control by the national administration. It was established before the turn of the twentieth century and has remained New Zealand's governance model in the new professional era. A comparative discussion of the different organizational structures in the northern and southern hemispheres shows how the sport is vulnerable to the contrasting governance systems characterized as 'club - versus - country'. Drawing on Leifer's account of the transformation of the major leagues in North America, the article investigates how the tension between hierarchical control by a central authority and the drive for local autonomy by clubs is resolved. It details the early establishment of local and national amateur rugby union competitions in New Zealand and argues that these 'professional-like' competitions represented a strategic compromise by the NZRU. In the global professional era, the NZRU has retained central control over the sport and players through the establishment of NZRU contracts to players and coaches in the five New Zealand Super 14 teams. While the wealthy English clubs exercise a considerable degree of control relative to the English RFU on the issue of player releases for national representation, the current tension in the New Zealand system resides in the saturation of the local player/coach labour market and the ability of players and coaches to exit for betterpaying contracts in the northern hemisphere.
\end{abstract}

\section{Introduction}

Despite the existence of amateur regulations in rugby union until 1996, the worldwide governance of the sport has been characterized by contrasting systems. This article provides a discussion of the governance systems in New Zealand in the amateur and professional periods and contrasts these developments with those in England. The article begins by explaining the exceptional New Zealand system of popular amateurism. This included successful local and national competitions and a strong national team governed by a national administration with central control and authority which helped secure rugby union as the national game. In contrast to this goal of producing successful national teams, the establishment of an English system in the late nineteenth century was characterized by a concern with clubs both before and after the split and the establishment of the professional game of rugby league in 1895. While clubs in England had direct representation on the national body (the RFU), clubs in New Zealand were governed by provincial unions whose representatives together formed

*Email: camilla.obel@canterbury.ac.nz

ISSN 1466-0970 print/ISSN 1743-9590 online

(C) 2010 Taylor \& Francis

DOI: $10.1080 / 14660971003780362$

http://www.informaworld.com 
the national body, the New Zealand Rugby Football Union (now the New Zealand Rugby Union; NZRU ${ }^{1}$ ). This delegated system of governance, whose authority is based on its legitimacy as the elected body, formed part of the sport's early hierarchical structure and it has extended beyond the amateur period to the current professional era where governance has been further delegated to a reduced board. This article traces the tensions in the New Zealand system, highlighting that competitive amateur competitions were sanctioned by the NZRU as a solution to the provincial unions' desire for local autonomy despite international concern that these competitions were a form of professionalism. It goes on to explain how organizational tensions in the professional period are provoked by players' and coaches' mobility. The current solution, in the form of the transnational Super 12/14 competition with a central contracting structure, a national player-transfer system and the nonselection of overseas-based players and coaches, has been introduced to combat the vulnerable, peripheral position of the New Zealand game relative to the economic power of the clubs in the northern hemisphere.

\section{The (elusive) national goal of All Black success}

Until a couple of decades ago, concern with commercial matters was frowned upon throughout much of the rugby union world. While debates about player transfers and transfer fees, distribution of media sponsorship and the growing gap between the richest and poorest clubs have occupied fans and administrators of association football worldwide for decades, among rugby union followers a concern with how to finance the sport, distribute income and expand markets was generally discouraged. That said, there were rumours of 'shamateurism', of players being paid 'under-hand', and some voiced concerns about what they saw as an overemphasis on competitiveness, both of which were said to be counter to the principles of amateurism. Much of this criticism came from the northern hemisphere and was directed at developments in the southern hemisphere. Not surprisingly, the concept of a Rugby World Cup (RWC) was promoted by the national administrations of Australia and New Zealand. As predicted, the inaugural tournament in 1987 ignited audience interest and the income-generating possibilities in the sport, but it also highlighted problems with how to manage this income.

In the case of New Zealand, the RWC was crucial in reconfirming the position of rugby union as the nation's most popular game, a position that had been challenged in the 1970s and 1980s when the NZRU had maintained contact with the South African rugby authorities despite international condemnation and internal protest. ${ }^{2}$ Despite the enormous interest and national investment in maintaining New Zealand as the number one country in the sport, winning the Rugby World Cup has remained elusive. The shock exit of the national New Zealand 'All Black' team in the quarter-final knockout round of the 2007 RWC again ignited the debate over the different playing styles and governance structures of the game in the northern and southern hemispheres. The northern hemisphere traditional stronghold of the sport in the UK accuses the southern hemisphere game in New Zealand, Australia, South Africa and the Pacific nations of playing a kind of hybrid game of rugby union and rugby league that favours running with the ball and try scoring. ${ }^{3}$ By contrast, the southern hemisphere rugby nations reject the northern hemisphere rugby style as outmoded and boring, with too much emphasis on forward play and kicking. Underlying this debate is a contrast in organizational and economic structures that shape the game in two contrasting directions. 
This article traces some of the organizational strategies pursued by the NZRU and highlights how these strategies were central to preserving rugby union as the national sport in New Zealand and in securing the international strength of the All Black team. This discussion, which emphasizes struggles for control between the national union and provincial unions, and between players and the NZRU, draws on a comparison with the organizational struggles in the UK, particularly England. These struggles for control, characterized as club versus country, emphasize the battles between club owners and national administrators for control over competitions and the availability of players for national teams. This article begins by showing how the popularity of the 10 amateur game in New Zealand was secured through the early establishment of interprovincial competitions with teams attached to provincial centres throughout the country. This argument, emphasizing organizational strategies, differs from the local accounts of the centrality of the national men's All Black team as a result of its early northern hemisphere tours, popularly regarded as iconic moments in the nation's 15 history, and for establishing a sense of national identification. ${ }^{4}$ It also questions, rather than takes for granted, amateurism as an explanation for the organization of the sport. It does so by drawing on an argument about professional leagues as a model of organizing popular support for sports. ${ }^{5}$ New Zealand 'amateur leagues' show both similarities to and differences from the professional leagues in the North American and European contexts. A key feature of the New Zealand governance model of rugby union is the centralized control exerted by the national administration.

The article extends the observation about leagues and control by the national administration to show how in the current professional era, the governance model of rugby union in New Zealand, in contrast to that in the northern hemisphere, continues to rely on a high degree of control exercised by a central administration. This has ensured that the national All Black team has continued to be the focus of the competitive infrastructure where player mobility is firmly regulated and subordinated to the 'nation' such that the club versus country relationship favours 'country' while ensuring 'club' (in this case provincial unions and in particular those hosting Super 14 teams) welfare. There are two aspects of the reconfigured professional game that pose a threat to the previously stable and successful New Zealand game: the dominance of northern hemisphere clubs relative to their national unions affects the availability of players for these national teams - and this has the knock-on effect of lowering the appeal of test matches involving the All Black team; and northern hemisphere clubs' financial strength acts as a pull for southern hemisphere players and coaches seeking better remuneration. Both of these factors threaten to undo the position of rugby union as the national game in New Zealand.

\section{Explaining amateur rugby's popular appeal}

Rugby union established itself as the national, popular game in New Zealand before the turn of the twentieth century. This "exceptional' 6 position was enjoyed in only a few other nations, including Wales, the Pacific nations and among the dominant, minority white community in South Africa. In these countries, a kind of popular amateurism evolved which included the careful managing of competitions overseen and centrally controlled by a national union. Thus, contrary to common perceptions about amateurism as fostering exclusivity and a rejection of market solutions for securing games' popularity, in New Zealand, rugby union came to enjoy popular support before the turn of the twentieth century due to organizational strategies 
involving a high degree of centralized control in return for fostering the spread of the game through local and national competitions.

Contrary to Markovits and Hellerman's claim that '[rugby] union had no leagues', 7 it was exactly the carefully managed competitive structures that fostered rugby union's popularity in New Zealand as it did in Wales, and in the north of England. ${ }^{8}$ Rugby union's popularity in New Zealand was fostered through the development of club and interprovincial matches which from the late 1880s attracted gatherings, equal to the size of professional First Division soccer crowds in England, ${ }^{9}$ eager to watch the most skilled local players perform against other regions' best players. Despite the claim that 'Welsh rugby was watched by larger numbers of spectators than anywhere outside of the North of England', ${ }^{10}$ it did not take long before provincial teams in New Zealand could match 'the lustrous Swansea side of the early 1900s [which] regularly drew crowds of 20,000 home and away'. ${ }^{11}$ In fact, the New Zealand challenge competition, the Ranfurly Shield introduced in 1902, gained a reputation as 'the goose that lays the Golden Egg' and 'the greatest money spinner ever in the Rugby world'. ${ }^{12}$

Drawing on Eric Leifer's observations concerning the organization of 'leagues' in the North American context, together with aspects of the two early New Zealand representative All Black players, David Gallaher's and John William Stead's account of the early colonial organization of rugby union in New Zealand, ${ }^{13}$ an argument can be made that the popularity of amateur interprovincial rugby union competitions in New Zealand rested on the adoption of aspects central to the organization of professional competitions. The establishment of domestic, amateur rugby union competitions served to cultivate and secure 'enduring or regular publics'. ${ }^{14}$ This observation provides an explanation, different from previous ones that emphasize the role of the All Black team as a focal point for national identification, which explains how, given the growing popularity of rugby league in Australia and New Zealand in the early part of the twentieth century ${ }^{15}$ and the very few international matches involving the All Black team, the union game maintained its position as the national, popular game in New Zealand. ${ }^{16}$ Rather than professionalism, introduced in 1996, representing a radical change in organizational strategies, these early centralized strategies for cultivating and maintaining the game's popularity and strength have continued into the professional era.

Drawing on Leifer's comparative historical and economic sociological account of the transformation of the major leagues in North America, this article investigates how the tension, characteristic of all team sport, between hierarchical control and the drive for local autonomy is resolved. This tension was at the heart of the conflict that split the game in $1895^{17}$ and it has been at the forefront in disputes over the introduction and organization of professional rugby union a century later. In the century of amateur rugby union, both local and international disputes, relating to the contrasting goals of competitive outcomes and the employment of an amateur ethos, have characterized the sport. Today, the disputes no longer concern amateur goals; rather 'clubs' and 'nations' confront each other over the regulation of player mobility.

Leifer's organizational analysis of the four professional major leagues shows that success in cultivating enduring local publics for professional teams in the period before World War I rested on the organization of leagues and the attachment of teams to cities. After World War II, he shows that national publics were cultivated through the attachment of leagues to national television broadcasters. Leifer's central insight is that in order for owners to achieve financial viability they had to give up their local 
autonomy, change their view of winning as being the most effective way of ensuring financial prosperity, and agree to affiliate into a centrally organized league. He therefore shifts attention for the explanation of the game and the generation of identification to the organizers of leagues and the support for teams. The focus becomes not the game in general, but relations between teams.

According to Leifer, the central organization of a limited number of teams into leagues involved in closed circuit home-and-away pennant races was the first step towards solving some of the owners' collective problems. The control over players' movement and the allocation of teams to large cities was the second. These mechanisms enabled the attachment and cultivation of regular local support for city-based teams, ensuring individual team's survival and the overall viability and prosperity of the leagues. Later the introduction of air travel and national television broadcasting created the opportunity for leagues to cultivate national audiences. For Leifer, the significance of these developments is that they represented a shift in organizing 15 professional sports from a focus on 'gathering crowds for matches to creating publics'. ${ }^{18}$

Although it is useful to think with Leifer's argument concerning how to cultivate support for sports, amateur rugby union in New Zealand did not require all of the organizational features of North American professional sports leagues. Yet, national administrators' desire to cultivate and maintain the game's popularity and to strengthen the All Black team, while maintaining ties with the four national unions in the United Kingdom and Ireland, the 'Home Unions', required centralized authority to regulate local relations. Provincial rugby unions (rather than 'clubs') were not business-like 'franchises', as in the case of teams in the North American professional leagues, but rather reflected European soccer clubs, about which Whitson notes that they were "part of non-profit, multi-sport "clubs" managed by boards composed by local business people' and attached to 'civically rooted, less entrepreneurial structures' ${ }^{19}$ Although both clubs and provincial unions in New Zealand and England were based on the amateur ethos, their organizational goal differed and therefore also their versions of amateurism. From the grassroots to the national level the overriding goal was competitiveness culminating in a strengthened All Black team. ${ }^{20}$ By contrast, from club level and through to the RFU, volunteerism characterized English rugby and clubs were 'friendly institutions' hosting 'slightly chaotic parties'. ${ }^{21}$

Despite these differences in the institutionalization of sport both among and between professional and amateur sports, which relate to the ownership of teams, the focus on financial gain and the contracting of players, Leifer's analysis provides a way of explaining the success of the New Zealand amateur rugby union competitions. More significantly, the adoption of some of the organizational features of professional competitions meant that rugby union organizers would not only face some of the problems and opportunities affecting professional sports, but that they would also become embroiled in both domestic and international disputes over professionalism. The NZRU's solution to these disputes was to deny professionalism while at the same time ceding power to provincial unions to pursue competitions that utilized the same means as professional competitions to generate income and spectator support. In doing so, the NZRU controlled the suspicion from the Home Unions that it was pursuing professional competitions. For provincial unions, in particular the larger citybased unions, it meant that interprovincial competitions proved to be very popular with local and later national audiences providing these unions with, first, high gatetakings, later sponsorship income and, most recently, the ability to contract star 
players. For the NZRU, these competitions provided the vital foundation for the production of All Black players.

\section{Organizational efficiency in a centrally governed system}

Disputes over what it meant to be an amateur athlete and how amateur competitions should be organized occupied national rugby union administrators for more than a century. These conflicts most famously included the early internal rupture of the game as a result of the development of cups and league competitions in the north of England whose popularity and inclusion of working class and entrepreneurial communities encouraged the introduction of payment to players and ultimately resulted in the split and the establishment of the 'northern' professional, rugby league game. Externally, early relations between the Home Unions were similarly characterized by tension over the need to surrender national authority to a supranational body and the desire to protect national interests. Thus, the English RFU initially refused to join the newly established International Rugby Board (IRB) in 1887 until it had been granted a dominant position and its point system for scoring adopted, and in 1897 the Welsh RFU withdraw briefly from the IRB following the dispute over the 'testimonial' to the famous Welsh player Arthur Gould. ${ }^{22}$ In the case of New Zealand, it was the sending and receiving of national teams that provoked the establishment of the 'NZRFU' in 1892. The first national team assembled in New Zealand to tour Australia in 1884 consisted of players selected from only some of the existing provincial unions, including Otago, Canterbury, Wellington and Auckland. This tour and later the northern hemisphere tour by the privately organized 'Native' team in 1888 provoked tension between provincial administrators and was potentially more damaging for those administrators eager to foster international relations with the Home Unions. ${ }^{23}$ Once formed, the national body quickly sought to subordinate provincial unions, control local competitions and punish any infringements of the amateur principles.

The New Zealand centralized organization in the amateur period, in which the tensions between 'clubs' and 'country' were resolved through the subordinating of provincial unions, served two national purposes: the cultivation of popular and strong competitions that could produce competitive national teams, and protection against professionalism. This organization required that local, district-based clubs were subordinated to provincial unions, which in turn were governed by the national union. The efficient relations between these three levels are explained in this description by Gallaher and Stead:

There is no unnecessary piece of governmental machinery, and the whole fits together with splendid exactness. The New Zealand Rugby Union being the chief authority, it has immediately below it the various provincial Unions, each province having its own union in the same way as with English counties, but a province is very much bigger and a more unwieldy thing than the English county, Auckland, for instance, being more than four hundred miles from one end to the other. In each province there are several country Unions, subservient directly to the provincial Union, and through it to the head body. After the provincial and the country Unions come the clubs. ${ }^{24}$

This development contrasted with the English RFU's inability to contain club matches as exclusively 'friendlies' and the English clubs' autonomous establishment, as the northern English county cup and league developments showed. Gallaher and Stead described those developments as 'promiscuous'. They point out that the establishment 
of provincial unions, affiliated to the national union, with authority to control not only the location of local clubs, but also their management, was the crucial means of ensuring both protection against professionalism and the viability of clubs and competitions:

...in Auckland, which we are particularly considering, there are several clubs called by the names of the respective districts of the town from which they draw their players. Clubs are not organised promiscuously in New Zealand as they are in Britain, [...] The Union decides what clubs there shall be, and supervises their management. In doing so it particularly desires to ensure the thoroughness and effectiveness of the working of each club, the equality of all of them so far as conditions and opportunities are concerned, the maintenance of strict amateurism throughout, the prevention of one club being completely overshadowed by another by reason of superior financial resources, or by any social or other non-financial inducement that it might offer to players to belong to it, and too easily facilitates for changing clubs. ${ }^{25}$

The success of this extraordinary system of 'organizational efficiency' might be exaggerated in these accounts but they nevertheless highlight that centralized power and local subordination characterized the New Zealand rugby governance model. This organizational efficiency contrasted with the English 'amateur' organization as referred to by Malin and Malcolm, Sheard and White, who suggest volunteers resisted overly organized and formalized competitions because they feared that such formalization would lead to over-serious play, violence, professionalism and spectatorism. ${ }^{26}$ Not surprisingly, there were expressions of local resistance by New Zealand provincial unions and clubs and concessions granted by the national union throughout the amateur period. Until the 1970s, most New Zealand amateur, interprovincial rugby union matches were played as 'friendlies' or as a challenge a provincial team issued to another team. These matches were not subject to the kind of rationalization and calculation that characterized professional competitions with teams organized into divisions or leagues, match victories translated into points and teams' standing throughout the season measured. However, those organizers keen to popularize amateur rugby union matches did introduce cup and league competitions.

As in the north of England and Wales, the New Zealand game became organized to encompass and encourage both player and spectator involvement from the late nineteenth century. In both New Zealand and Wales, a kind of democratic or popular amateurism was encouraged as a way of popularizing the game. ${ }^{27}$ While administrators in New Zealand did not allow payment to players (until much later in the 1980s and through sanctioned promotional company structures - see below), they did hire coaches, charge money at the gate, provide tour allowances to All Black players and encourage players to train and improve their skills.

In contrast to the southern English clubs, only some of which charged spectators for admission to club matches, ${ }^{28}$ all provincial unions in New Zealand began to charge spectators for admission to matches against visiting provincial teams and to club matches before the turn of the twentieth century. Additionally, Gallaher and Stead explain that each club had several teams which participated in graded cup and league competitions:

Each club runs three fifteens, and the same arrangements in every respect are made for the seconds and thirds as for the firsts. The Union offers three Cups for competition by the district clubs on what in Britain is known as the League system, one Cup being allotted to each grade of players in the various clubs ... the competition in each case is strictly limited to players of the proper class. ${ }^{29}$ 
This grading of players into first-, second- and third-graded club competitions restricted players to only the competition-grade to which he was 'classed'. The provincial union committee decided any promotion of players and a player could not play in the grade from which he was promoted. This ensured that the lower grades were as competitive and 'scarcely inferior in point of interest to those of the grade above'. While the residential regulations encouraged balanced competitions and thus 'spectatorism', clubs were prohibited from owning their venues and the provincial unions seized the gate-takings from all club and interprovincial matches staged at the provincial union stadium, thus 'keeping pure amateurism'. ${ }^{30}$

This promotion of spectatorism through cups and leagues raised the Home Unions' suspicion of 'veiled professionalism' in the colony ${ }^{31}$ and placed the national administration in New Zealand in a precarious position between the Home Unions and its own provincial unions. The problem that the NZRU faced was that its dedication to the All Black team required a form of decentralization which promoted highly competitive and graded domestic competitions capable of ensuring that the NZRU got 'all football worth out of the youth of the nation [which] is necessary if it aspires to hold its own, or a little more, in competition with its contemporaries'. ${ }^{32}$

\section{Amateur friendlies and local cups and leagues}

Despite the fact that interprovincial matches were friendlies and not formalized to the same extent as the local, graded club competitions, consistent with the NZRU's and some provincial delegates' desire to resist competition structures involving the 'grading of union against union in merit tables or leagues', ${ }^{33}$ they did generate large spectator interest. At the beginning of the twentieth century a total of around 50 interprovincial friendlies were played and between the two World Wars up to 100 matches were staged annually. ${ }^{34}$ While the number of friendlies grew, and regional cup competitions were established between 1906 and 1965 involving two-thirds of all provincial unions, interprovincial friendlies eventually became incorporated into national, interprovincial competitions, the Ranfurly Shield and the National Provincial Championship (NPC), established three-quarters of a century apart.

The NZRU's agreement to introduce the Ranfurly Shield in 1902 represented the first move towards involving city-based provincial teams in a national competition. The amateur rules of the competition required that the Shield be contested in "challenge matches' - 'the New Zealand Union seeing to it that they [the Shield holders] are not over done by challenges'. ${ }^{35}$ This meant that the competition involved only half a dozen provincial teams in the few matches staged each year. ${ }^{36}$ Despite these restrictions, the amateur competition was highly successful with local spectators. Crowds of 20,000 spectators for Ranfurly Shield matches were not unusual from the 1920s onwards. This competition became the most significant revenue-generating means for provincial unions enabling a few, the largest city-based unions, Auckland, Wellington and Canterbury, to claim a powerful position vis-à-vis the NZRU. But, more significantly, the success of Ranfurly Shield matches was critical for the continued popularity of rugby union in the first half of the century when few All Black matches took place. However, this popularity may have contributed to the Home Unions' suspicion of 'professionalism' and their reluctance to tour New Zealand - after the Anglo-Welsh tour in 1908 a British team did not tour New Zealand until 1930, and this 'snub' is likely to have influenced the NZRU to restrict the number of the annual challenge matches. 
Overall, the financial benefits of the competition favoured only a few unions but its popularity helped foster and promote the game. In the period between 1902 and 1999 only 14 unions successfully defended the Shield, the Auckland and Canterbury unions dominated the Shield and only the Wellington union came close to achieving the success of these two large city-based unions. Despite the uneven benefits of the Shield competition, favouring the major provincial unions, these unions promoted the idea of a national 'league' in the 1960s. Similar development occurred in the northern hemisphere where gate-taking clubs in England and Scotland campaigned for the introduction of national club competitions. Yet, it was not until 1987 that all-inclusive 10 national club competitions with merit tables were introduced in England. ${ }^{37}$ In both hemispheres the introduction of televised sport and the broadcasting of the rival rugby league code likely boosted the position of the major gate-taking clubs in England and the larger provincial unions in New Zealand, both in favour of national competitions.

Following Leifer's argument, the introduction of these national competitions 15 represented a shift from gathering crowds for matches to creating enduring publics. The later establishment of the television-sponsored transnational Super 12 competition and the European club competition facilitated the establishment of enduring mediated national and transnational publics. In New Zealand, the introduction of the NPC with two, and later three divisions (and most recently, two 'leagues' - see below), represented a collective strategy to increase income for all teams involved as opposed to the previous individual strategy of creating winning teams to ensure local financial prosperity.

While the NZRU retained control over the NPC competition and issued rules to regulate it and the Ranfurly Shield, according to the provincial rugby union administrator Barry Smith, the provincial unions arranged matches at 'intensely fought out' annual NZRU meetings known as the 'Woolsale'. ${ }^{38}$ As a result, the first NPC season spanned from May until mid-October in an effort to accommodate the provinces' seasonal obligations. A consequence of the decentralized match arrangement was that the championship could be won before the end of the season, resulting in low spectator attendance at the end-of-season matches. It was not until 1985/1986 that changes to the NPC increased the uncertainty of the championship outcomes. The NPC became national and changes to the points scoring made teams benefit from close matches. These changes introduced an 'ordered performance inequality', ensuring that more teams remained contenders for the championship facilitating a season-long local interest in the competition.

Coinciding with these changes, the first live interprovincial match was broadcast on public television in $1986 .{ }^{39}$ The introduction of play-offs in 1992, which coincided with guaranteed live television coverage of the NPC, and the central organization of the draw were attempts to attract, for the first time, a national television public for live 40 play-off matches. Significantly, these competition changes came at a time when the NZRU was forced to compete for viewers with rugby league. From 1989, the Australian Rugby League Winfield Cup competition began to be broadcast live on a weekly basis to New Zealand viewers. ${ }^{40}$ This generated viewer interest in New Zealand and increased the income for the Australian rugby league clubs, which began offering several high-profile New Zealand rugby union players high-paying professional salaries to switch to play rugby league for their clubs. By 1995, and coinciding with the third RWC, this threat escalated as a result of media sponsorship 'wars' in both rugby codes. Tumult in rugby league was caused by a News Corporation proposal for a new Super League structure involving both the Australian and English rugby league 
premier competitions and which provoked a sharp rise in player contract offers to both established rugby league and star rugby union players. ${ }^{41}$ In rugby union, the Kerry Packer sponsored global World Rugby Corporation was ultimately unsuccessful in luring away the control of the game from the national unions. Backed by a News Corporation sponsorship deal worth US $\$ 555 \mathrm{~m}$ over 10 years, the national unions in South Africa, Australia and New Zealand (SANZAR) were successful in retaining control of the game and their players by offering professional contracts in return for introducing new competitions in the form of the transnational Super 12 and the Tri Nations competitions. ${ }^{42}$

A century after the first split in the rugby 'football' code the union game faced a new challenge in the form of professional player contracts and increased player mobility. Yet, this challenge which was provoked by media-sponsorship interest in both the rugby codes emerged as a result of the spectator interest and popularity of the local and emerging transnational competitions. Thus, Markovits and Hellerman's claim that 'Various cup competitions at the club level were only introduced in the 1970 s, the period in which Union, too, began a process of overt professionalization' ${ }^{43}$ neglects the early conflicts surrounding the establishment of cup and league competitions in the north of England and in Wales and uses the, later, English organization of the game as the model of explaining this particular amateur 'football' version. In doing so, they also completely neglect the popular organizational model of amateur rugby union that developed in New Zealand and in Wales.

\section{Tensions in a centralized system: success, failure and uneven global regulations}

In 1995, professional contracts replaced amateur eligibility regulations as the principle for allocating sporting opportunities for rugby union players. In the northern shemisphere, clubs controlled these contracts, much like the situation in soccer. In the southern hemisphere, national unions controlled contracts and introduced a national player-transfer system regulating provincial unions' player contracting and players' national mobility. The establishment of a new News Corporation-sponsored 'television league' - the Super 12 transnational SANZAR competition involving newly formed teams in New Zealand (5) and provincial teams from South Africa (4) and Australia (3), became controlled by the national unions in these countries. In contrast to this centralized control, in the northern hemisphere premier clubs, backed by wealthy new owners, dominated the 'open market' system. These contrasting systems created a global context in which player mobility was relatively unregulated. As a consequence of this, national unions in the southern hemisphere became increasing vulnerable to the economic power in the north where the wealthy clubs began contracting southern hemisphere players and coaches. While the shift to professional contracts introduced player labour markets and increasing global mobility, regulations in the amateur era did not completely exclude player mobility. Rather, as McGovern has shown with respect to soccer player-migration patterns, rugby player migration in the new professional era is shaped by tradition, early contact and social networks. ${ }^{44}$

Until 1995, player labour markets did not exist and players were tightly regulated. Player mobility was constrained through residence rules which required players to be resident in their province and a member of a local club for at least three weeks prior to selection for their provincial team, while amateur regulations prohibited players from accepting money in return for any service relating to rugby, in particular a move to the highest bidder. ${ }^{45}$ The few players who transferred between provincial unions 
within New Zealand officially did so because of work commitments and, later, increasingly to take advantage of educational opportunities. However, public speculation suggested that this form of mobility was underhand, or a form of shamateurism, which had produced a 'black market' where players moved to a new province in return for money or a 'rugby job'. This pattern of mobility was dependent on local sponsorship of clubs in both New Zealand and Europe. While accusations of shamateurism increased, this form of player mobility did not provoke a tension between individual players and the national team. Players such as Murray Mexted, Andy Haden and John Kirwan, ${ }^{46}$ based overseas in the off-season, were not excluded from All Black 10 selection, as is the case in the new professional game, as long as they were able to return home for trials and selection procedures.

'Rugby jobs' paved the way for indirect player payment provoked by the establishment of promotional companies by star players. Companies, such as John Kirwan's Forza Promotions in 1987 and Wayne Smith's Tryline in 1989, were copied 15 by provincial unions and the NZRU in the early 1990s. All Black Promotions, formed in 1994, received sponsorship from the Union's major sponsors, Steinlager, Coca Cola, Ford and Philips, and paid All Black players a fee of approximately NZ\$50,000 for promotional services for sponsors in 1995 leading up to the RWC and including the end of year/season northern hemisphere tour. Similar promotional companies were formed in the northern hemisphere, and while the NZRU's player payment was reported by be greater than these, star players in the northern hemisphere were expected to be able to earn as much as $£ 50,000$ a year through individual sponsorship deals. ${ }^{47}$ These forms of payment were considered crucial in the southern hemisphere where the rival rugby league code threatened to lure away the best international players with attractive contracts. Thus, prior to the introduction of 'fully' professional contracts, player payments were characterized by an uneven distribution dependent upon both the local and national administrators' attitude to player retention and welfare and the size of their respective sponsorship markets.

In contrast to the form of player mobility in the amateur period, which did not threaten the strength of the New Zealand game and the All Black team, the introduction of professional player labour markets has produced tension between elite players' power to move and the NZRU's efforts to secure the national team. The professional player labour market is geared to the highest bidder and the mobility of players and teams is the condition for the way the game is organized now. The NZRU's solution to this threat was to introduce centralized contracts for New Zealand players and coaches and thereby create an exceptional player/coach labour market subordinated to the national team. The NZRU justified this system of contracting, requiring players to participate in initially as many as five different teams and competitions, on the basis that it strengthened New Zealand teams. This exceptional player labour market 40 consolidated the NZRU's paternalistic control over its constituent members, provincial unions, coaches and players. In contrast to the early organizational form in which producing a strong national team was secured through the development of and central control over local and national competitions, the solution to protecting the All Black team in the professional era required the creation of new teams to participate in a transnational competition. The centralized contracts and the initial lack of an effective players' association ensured the lowest payment to New Zealand Super 12 players as well as highly differentiated, longer term, individually negotiated player contracts. ${ }^{48}$ It enabled the NZRU Super 12 selectors (including the Super 12 coaches) to control the drafting of players into the five Super 12 teams and to dictate the teams' 
composition, ensuring the establishment of five 'NZRU' teams, which would test and develop promising and established All Black players.

The Super 12 competition, restructured from the earlier Super 10 competition, ${ }^{49}$ was introduced in the traditional southern hemisphere 'pre-season' running between February and May and culminating in the Tri Nations series in June-July. The Super 12 and Tri Nations competitions thus fitted in with existing international and domestic competitions, but importantly added a minimum of 11 matches to the workloads of the country's best 150 players. It culminated in a Tri Nations series consisting of homeand-away matches between the three national representative sides in South Africa, New Zealand and Australia. The Super 12 competition included a play-off format similar to that introduced in the NPC in 1992. In the Tri Nations series, score-differentials were used to determine a winner in the event of a 'dead heat'. This latter competition regulation was changed to include an additional round with play-offs, while the Super 12 competitions was expanded to 14 teams (one new team from Australia and South Africa) after the renegotiation of the sponsorship deal between SANZAR and News Corporation in 2005.

To encourage the cultivation of local publics, the five New Zealand Super 12/14 teams were allocated to existing provincial unions. Rather than franchises, as in the North American cartel model of major leagues with franchises, these unions acted as 'caretakers' of the Super 12/14 teams, which were made up predominantly of players from within the 'region'. The regions were constructed by the NZRU by dividing the 27 first, second and third division provincial unions into five regions and 'attaching' a Super 12/14 team to the largest first division union within each region. By contrast, the selection of four South African provincial teams to participate in the Super 12/14 competition followed the promotion-qualification procedures for the earlier Super 10 competition to which the top four provincial unions in the domestic Currie Cup qualified. However, by 1998, the four South African Super 12/14 teams (with a fifth added in 2006) became regional as in New Zealand, with the best players selected from across all the 14 provincial unions. In Australia, the three (and now four with the inclusion of Western Australia) state representative teams, New South Wales, Queensland and Australian Capital Territory were automatically included in the competition.

This new 'television league' consisting of mostly new 'franchises' in a closed league structure represented the adoption of fully professional league structures with teams guaranteed inclusion season after season irrespective of performance and with no promotion-relegation system between this transnational league and national competitions. Yet, while this competition represents an adoption of 'fully professional' competition structures, the New Zealand organizational model of professional rugby union shows a high degree of continuity with the central control during the amateur period that sought to secure the national team through strong domestic competitions. The aim of securing the game as national and strengthening the All Black team today requires participation in a transnational league and players' involvement is controlled by the NZRU through the central contracting of the best 150 players and 5 coaches. This situation breaks with the tradition of securing professional teams' independence and the NZRU is in the exceptional situation of being the only buyer of rugby talent to the new competition.

To protect the local game against the effects of a professional player labour market, the NZRU swiftly sought Commerce Commission approval for the introduction of a player transfer system to take effect in $1997 .{ }^{50}$ The transfer system included 
a three-tiered structure: a maximum of five transfers to a provincial union of which a maximum of three of these can be Super 12/14 players or above; a transfer fee cap set centrally limiting the fee a provincial union can demand for the release of a player, the maximum being NZ $\$ 100,000$ for a current All Black player; and a transfer window of one month per year. ${ }^{51}$ The introduction of a national transfer system and an All Black and coaching selection policy that precluded overseas-based player and coaches from selection in 1996, further sought to prevent the effects of a global professional player and coach labour market from exposing the economic inequality between provincial unions and the weakness of the smaller New Zealand market relative to the economic strength in the northern hemisphere.

Not surprisingly, New Zealand provincial unions reacted differently to the new professional regulations, governance structures and competitions. Added to their concerns over the introduction of a professional competition with new teams, was the change in governance structures which followed changes in amateur sports both nationally and internationally. ${ }^{52}$ While the governance of both the provincial unions and the NZRU in the amateur period consisted of elected representatives from, respectively, the clubs and the provinces into unions and the national council, in the new professional era these bodies have been replaced with boards consisting of fewer members, some of whom are elected for their business expertise and sponsorship connections. Yet, despite this 'professionalization' of the governance of the game, the influence of the provincial unions was demonstrated in the new 'downsized' NZRU board in 1995. The new board shrank from being a 19-member council dominated by zone representatives to a 9-member board, again dominated by provincial or more accurately regional representatives and with only two independent members with business connections, despite recommendations in the Boston Consulting Report for greater delegation to a professional management team. ${ }^{53}$

Despite this show of power by the provincial unions, those unions not hosting Super 12/14 teams were concerned that the existing national competitions would diminish in popularity and thus damage their financial prospects, whereas those hosting Super 12/14 'franchises' were concerned that they would not control 'their' teams. The solutions to these tensions were to grant the provincial unions hosting Super 12/14 teams the gate-takings for their home games, which they were required to share with the other provincial unions in their region. Also, and after much deliberation, the NPC was revamped in 2006 into a two-league competition without promotion-relegation, effectively expanding the previous first division NPC group of provincial teams from 9 to 14 in the new Air NZ Cup competition, and separating it from the AA Heartland Championship involving the bottom 12 provincial teams. Lastly, the NZRU has introduced a salary cap for provincial teams which, it has argued, is a means to protect the smaller and less financially secure provincial unions 40 and limit the wealthier provincial union from creating 'super' teams. ${ }^{54}$ From 2006, provincial unions' 'A' team's total salary package cannot exceed NZ\$2m. The cap includes provincial contracts and notional values for players depending on their ranking, less a discount for the most senior players including current All Black players and eight-year provincial veterans.

45 Despite these regulations in the national market, financial and competitive differences between provincial unions have intensified rather than decreased. The ability of provincial unions to strengthen their representative teams with 'imported' players has enabled the wealthiest to dominate the domestic player transfer market. The establishment of the five regional Super 12/14 teams as NZRU franchises 
subordinated to the All Black team, and their allocation to the five largest city-based unions has formally institutionalized the strength of these unions. In addition, by creating 'farm systems', through the establishment of rugby academies recruiting younger players directly from school competitions, these unions have created a new income source from the new transfer market and contributed to a weakening of the links between schools, clubs and provincial unions. This new flow to and development of player talent by these unions are critical for their maintenance of a Super 12/ 14 'franchise'.

The centralized contracting of players in New Zealand and the establishment of new teams to participate in a transnational league contrasted with the contracting of players by elite clubs in the northern hemisphere and reconfirmed their strength relative to the national unions. While professionalism was ushered in in the southern hemisphere by the national unions in the form of a transnational 'league' competition, the English RFU instituted a moratorium on player contracting in the first season of professional rugby union, although not of the clubs respected it, as the case of Sir John Hall's purchase of Newcastle-Gosforth Rugby Club and subsequent contracting of players showed. The emergence of financial investments in English rugby union clubs began to characterize the field of northern hemisphere rugby and, not surprisingly, the greater sporting and economic opportunities offered by these clubs encouraged increasing migration of players and coaches to the northern hemisphere. ${ }^{55}$ The leading English clubs formed the English Professional Rugby Union Clubs (EPRUC now Premiership Rugby) as a joint venture or oligarchy in December 1995 and this powerful group has since then been a key actor in negotiations over the new governance model in English rugby union. ${ }^{56}$ While the introduction of professional contracts was met with concern by the northern hemisphere unions in 1995, leading to the English and Scottish national unions banning their top clubs from participating in the new European Cup ${ }^{57}$ northern hemisphere clubs' power relative to their national unions was highlighted several times in the first decade of professional rugby union. Despite the English and Scottish unions agreeing to join the European Cup in the 1996/1997 season, disputes between the RFU and the leading clubs continued and escalated to the point where premier clubs resisted releasing players for international duties and threatened to withdraw from the European Cup, a threat they acted upon in the 1998/ 1999 season. ${ }^{58}$ The Premiership clubs' power relative to the RFU increased following an agreement between it and the Professional Rugby Players' Association. Attempts at establishing agreement between the Premiership clubs, the Professional Rugby Players' Association and the RFU included, first, the 1996 Mayfair Agreement, the 1998 Leicester agreement, the 2001 long-form agreement and the 2004 elite-player scheme, all of which offered brief periods of 'peace' between the elite English clubs and the RFU on matters including promotion and relegation between the top two divisions, and the release of players for internationals including the Six Nations, tours and tests. ${ }^{59}$ In the midst of these negotiations divisions between the clubs increased as a result of the forming of the Premiership in 1998 and disagreements over the exact workings of the promotion-relegation structures. Most recently, in 2007 a new eightyear, $£ 100 \mathrm{~m}$ agreement between the Premiership clubs and the RFU looks likely to be ratified. It involves resolutions on international player release periods, financial compensation to the clubs, promotion and relegation to be guaranteed for the duration of the agreement, season structure, the establishment of a Professional Game Board (PGB) to run the professional game, and the streamlining of the England squad structure. ${ }^{60}$ 


\section{Future uncertainty in a professional game}

Despite the tensions in the northern hemisphere game, both clubs and national teams have continued to attract players and coaches from the southern hemisphere who perform in new transnational or expanded international competitions. Thus, while the game of rugby union continues to be one played by nations, its global span now exceeds the former 'orderly' Commonwealth community and New Zealand's place in it has become increasingly uncertain. As New Zealand's exceptionalism is celebrated in the new global game, its dominance is threatened. New Zealand's dominance in the professional era was initially achieved through Super 12/14 teams but, in the new era the All Black team's advantage is no longer assured, as it was in the amateur period, through the adoption of organizational aspects of professional sports. In the context of a professional game, organizational solutions at club and national levels, as Leifer has pointed out, no longer guarantee success. Success, as the global media companies understand it, is now measured by the success of the global game. The respective positions of nations and clubs within the game are therefore necessarily uncertain. The All Black team is not guaranteed a place among the top three rugby nations, as the recent 2007 RWC result shows, and this has increased the pressure on the NZRU to develop new strategies to further protect the national game and halt the All Black team's loss of ground to opposition in bigger overseas markets. The continued exceptionalism and dominance of New Zealand rugby is therefore threatened in the new global game.

\section{Notes}

1. The NZRFU dropped 'football' in its name in 2006. I use the new shorter abbreviation.

2. R. Thompson, Retreat from Apartheid; Fougere, 'Barbed Wire and Riot Squads'; S. Thompson, 'Challenging the Hegemony'; Nauright, 'Race, Rugby and Politics'; Richards, Dancing on our Bones.

3. Torres and Hager 'Competitive Sport, Evaluation Systems'.

4. Richardson, 'Rugby, Race and Empire'; Sinclair, A Destiny Apart; Phillips, A Man's Country?; Nauright, 'Sport, Manhood and Empire'; Zavos, Ka mate! Ka mate!; Fougere, 'Sport, Culture and Identity'; Perry, 'Cinderella and the Silver Mercedes'.

5. Leifer, Making the Majors.

6. The term 'exceptional' is drawn from the argument about the absence of soccer in the North American sports space in Markovits and Hellerman, Offside. Soccer and American Exceptionalism. Here the term is used to explain the different institutionalization of the game of rugby union.

35 7. Markovits and Hellerman, Offside. Soccer and American Exceptionalism, 29.

8. Dunning and Sheard, Barbarians, Gentlemen and Players; Collins, Rugby's Great Split.

9. Vamplew, Pay up and Play up the Game, 63.

10. Williams, 'Rugby Union', 315.

11. Ibid., 316.

12. Carman, Ranfurly Shield Rugby, 225, 238.

13. Gallaher and Stead. The Complete Rugby Footballer; Palenski, Chester, and McMillan, The Encyclopaedia of New Zealand Rugby, 2-3. David Gallaher was the captain of the All Black team that toured the northern hemisphere in 1905 and captained all tests except for the one against Ireland, due to injury, which was captained by John William ('Billy') Stead. Gallaher retired from playing after the tour and served as the sole Auckland selector between 1906 and 1916 and as New Zealand selector between 1907 and 1914.

14. This section draws on the work by Leifer, Making the Majors. Leifer distinguishes between enduring publics and infrequent crowds of the North American major leagues. He argues that the large number of people who daily pay attention to major league sports either by attending or viewing games on television or by reading the sports pages in the daily newspaper, listening to sports radio or buying major league products constitute a sports public by the regularity with which they are reactivated. He distinguishes these publics from the 
crowds or gatherings of earlier times who attended to major league sports on an infrequent basis. His shows that the changes to the North American leagues are characterized by the constitution or creation of publics.

15. Coffey, Canterbury XIII.

16. Only three All Black teams toured Britain between the establishment of the NZRU and World War II. The first two, which toured Britain in 1905-6 and 1924-5, were later affectionately branded as 'The Originals' and 'The Invincibles'. In 1935 a third All Black team toured the northern hemisphere.

17. Dunning and Sheard, Barbarians, Gentlemen and Players; Collins, Rugby's Great Split.

18. Leifer, Making the Majors, 59.

19. Whitson, 'Circuits of Promotion', 58.

20. Fougere, 'Sport, Culture and Identity'.

21. O'Brien and Slack, 'Analysis of Change'; Malin, Mud, Blood and Money.

22. Smith and Williams, Fields of Praise, 474; Howe, 'Professionalism, Commercialism and the Rugby Club', 167; Williams, 'How Amateur was My Valley', 253; Williams, 'Rugby Union', 317; Collins, Rugby's Great Split, 165.

23. Ryan, Forerunners of the All Blacks.

24. Gallagher and Stead, The Complete Rugby Footballer, 37.

25. Ibid., 38-9.

26. Malin, Mud, Blood and Money; Malcolm, Sheard, and White, 'Changing Structure and Culture'

27. Smith and Williams, Fields of Praise, 171.

28. Dunning and Sheard, Barbarians, Gentlemen and Players, 245; Williams, 'Rugby Union', $320-1$.

29. Gallagher and Stead, The Complete Rugby Footballer, 40-1.

30. Ibid., 42, 47.

31. Vincent, 'Practical Imperialism'.

32. Gallagher and Stead, The Complete Rugby Footballer, 36.

33. Richardson, 'The Invention of a National Game'.

34. Swan, History of New Zealand Rugby Football 1870-1945; Swan, History of New Zealand Rugby Football Volume 2.

35. Gallagher and Stead, The Complete Rugby Footballer, 51.

36. Palenski et al., The Encyclopaedia of New Zealand Rugby, 230-6.

37. Dunning and Sheard, Barbarians, Gentlemen and Players, 263-4; Williams, 'Rugby Unions'.

38. Garland, Fields of Glory, 2.

39. Day, 'Sport, the Media and New Zealand'.

40. Becht, A New Breed Rising.

41. FitzSimons, The Rugby Wars; Hutchins, 'Rugby Wars'; Rowe, 'Rugby League in Australia'; Rowe, Lawrence, Miller and McKay, 'Global Sport?'.

42. Obel, 'Local and Global Publics'.

43. Markovits and Hellerman, Offside. Soccer and American Exceptionalism, 29.

44. McGovern, 'Globalization or Internationalization?'

45. NZRFU, Handbook, 89.

46. Misa, 'The Monday-to-Friday John Kirwan'; Howitt and Haworth, Rugby Nomads, 286, 288.

47. Jones, 'Full-time League'.

48. Dabscheck, 'Trying Times'.

49. Obel, 'Local and Global Publics'.

50. Rugby Union Players' Association.

51. Pengilley, 'Super League'.

52. Houlihan, Sport, Policy and Politics; Cameron, Trail Blazers; Whitson and Macintosh, 'Rational Planning'.

53. Boston Consulting Report, Taking Rugby Union. The NZRU commissioned the report from the Boston Consulting Group in 1993 the significance of which was that the union had gone to an independent firm to gain advice on how to protect the national position of the sport. Many of the recommendations in the report, not surprisingly given the centralized structure of New Zealand rugby union, were modelled on North American professional leagues rather than the community-based club model of European professional sports such as association football. 
54. Robson, 'Crunching the Numbers'.

55. Obel and Austrin, 'End of Our National Game'.

56. Morgan, 'Optimizing the Structure'.

57. Cleary and Griffiths, Rothmans Rugby Union Yearbook.

58. Trelford, 'Brisbane Debacle'.

59. Baldock, 'Rugby Union'.

60. Cain, 'Peace Deal puts England'.

\section{References}

Baldock, A. 'Rugby Union: English Rugby's Club Versus Country Crisis Deepens', Daily Post October 28, 2005.

Becht, R. A New Breed Rising: The Warriors Winfield Cup Challenge. Auckland: HarperCollins, 1994.

Boston Consulting Group. Taking Rugby Union into the 21st century: Strategic Choices Facing the New Zealand Rugby Football Union. Auckland: The Boston Consulting Group - Incorporating Pappas Carter Evans \& Koop, 1994.

Cain, N. 'Peace Deal Puts England on Level Footing with Rivals; Rugby Union: Guinness Premiership', The Sunday Times, Sepember 30, 2007.

Cameron, J. Trail Blazers: Women Who Manage New Zealand Sport. Christchurch: Sports Inclined, 1996.

Carman, A.H. Ranfurly Shield Rugby: The Complete Book of Match Reports, Comments, Teams, Photographs and Records. Wellington: Reed, 1960.

Cleary, M., and J. Griffiths. Rothmans Rugby Union Yearbook 1996-97. London: Headline Book Publishing, 1997.

Coffey, J. Canterbury XIII: A Rugby League History. Christchurch: Canterbury Rugby Football League, 1987.

Collins, T. Rugby's Great Split: Class, Culture and the Origins of Rugby League Football. London: Frank Cass, 1998.

Dabscheck, B. 'Trying Times: Collective Bargaining in Australian Rugby Union', Sporting Traditions 15 (1998): 25-49.

Day, P. 'Sport, the Media in New Zealand'. In Sport, Society and Culture in New Zealand, ed. B. Patterson. Victoria University, Stout Research Centre: Dunmore Press, 1999.

Dunning, E., and K. Sheard. Barbarians, Gentlemen and Players: A Sociological Study of the Development of Rugby Football. Wellington: Price Milburn, 1979.

FitzSimons, P. The Rugby War. Sydney: HarperSports, 1996.

Fougere, G. 'Barbed Wire and Riot Squads - What is Being Defended? The Springbok Tour of 1981', New Zealand Journal of Cultural Studies Working Group Journal 2 (1981): 11-14.

Fougere, G. 'Sport, Culture and Identity: The Case of Rugby Football'. In Culture and Identity in New Zealand, ed. D. Novitz and B. Willmott, Wellington: GP Books, 1989.

35 Gallaher, D., and W.J. Stead. The Complete Rugby Footballer on the New Zealand System (facsimile), Christchurch: Kiwi Publishers, 1906/1998.

Garland, S.J. Fields of Glory: 21 NPC Years, 1976-1996. Auckland: HarperCollins, 1997.

Houlihan, B. Sport, Policy and Politics: A Comparative Analysis. London: Routledge, 1997.

Howe, P.D. 'Professionalism, Commercialism and the Rugby Club: The Case of Pontypridd RFC'. In Making the Rugby World. Race, Gender, Commerce, ed. T.J.L. Chandler and

$40 \quad$ J. Nauright. London: Frank Cass, 1999.

Hutchins, B. 'Rugby Wars: The Changing Face of Football', Sporting Traditions 13 (1996): 151-62.

Jones, S. 'Full-time League Role Not for Some', Sunday Star-Times, May 7, 1995 (London edition).

45 Leifer, E.M. Making the Majors: The Transformation of Team Sports in America. Cambridge, MA: Harvard University Press, 1995.

Malcolm, D., K. Sheard, and A. White. 'The Changing Structure and Culture of English Rugby Union', Culture, Sport and Society 3 (2000): 63-87.

Malin, I. Mud, Blood and Money: English Rugby Goes Professional. London: Mainstream Publishing, 1997. 
Markovits, S., and S.L. Hellerman. Offside. Soccer and American Exceptionalism. Princeton, NJ: Princeton University Press, 2001.

McGovern, P. 'Globalization or Internationalization? Foreign Footballers in the English League, 1945-95', Sociology 36 (2002): 23-42.

Misa, T. 'The Monday-to-Friday John Kirwan', North \& South, November, 1987.

Morgan, M. 'Optimizing the Structure of Elite Competitions in Professional Sport - Lessons from Rugby Union', Managing Leisure 7 (2002): 41-60.

Nauright, J. 'Sport, Manhood and Empire: British Response to the New Zealand Rugby Tour of 1905', The International Journal of the History of Sport 8 (1991): 239-55.

Nauright, J. 'Race, Rugby and Politics: New Zealand and South Africa 1921-1992', Journal of Physical Education New Zealand 26 (1993): 19-22.

NZRFU. Handbook. Wellington: New Zealand Rugby Football Union, 1994.

O'Brien, D., and T. Slack. 'An Analysis of Change in an Organizational Field: The Professionalization of English Rugby Union', Journal of Sport Management 17 (2003): 417-48.

Obel, C. 'Local and Global Publics: Shifting Popularity in Rugby Union and Rugby League'. In Time Out? Leisure, Recreation and Tourism in New Zealand and Australia, ed. H. Perkins and G. Cushman. Auckland: Longman, 1998.

Obel, C., and T. Austrin. 'The End of Our National Game: Rugby, Romance and Mobilities'. In Tackling Rugby Myths: Rugby and New Zealand Society 1854-2004, ed. G. Ryan, 173-93. Dunedin: Otago University Press, 2005.

Palenski, R., R.H. Chester, and N.A.C. McMillan. The Encyclopaedia of New Zealand Rugby (3rd ed.). Auckland: Hodder Moa Beckett, 1998.

Pengilley, W. 'Super League', New Zealand Law Journal (1998): 32-6.

Perry, N. 'Cinderella and the Silver Mercedes: Popular Culture and the Construction of National Identity'. In Culture and Identity in New Zealand, ed. D. Novitz and B. Willmott. Auckland: Bookprint Consultants, 1989.

Phillips, J. A Man's Country? The Image of the Pakeha Male - A History. Auckland: Penguin Books, 1987.

Richards, T. Dancing on our Bones: New Zealand, South Africa, Rugby and Racism. Wellington: Bridget Williams Books, 1999.

Richardson, L. 'Rugby, Race and Empire: The 1905 All Black Tour', Historical News 47 (1983): $1-5$.

Richardson, L. 'The Invention of a National Game: The Struggle for Control', History Now 1 (1995): 1-8.

Robson, T. 'Crunching the Numbers', Dominion Post, November 4, 2005.

Rowe, D. 'Rugby League in Australia: The Super League Saga', Journal of Sport and Social Issues 21 (1997): 221-6.

Rowe, D., G. Lawrence, T. Miller, and J. McKay. 'Global Sport? Core Concern and Peripheral Vision', Media, Culture and Society 16 (1994): 661-75.

Rugby Union Players' Association v Commerce Commission (No 2). New Zealand Law Review 3 (1997): 301-29.

Ryan, G.J. Forerunners of the All Blacks: The 1888-89 New Zealand Native Football Team in Britain, Australia and New Zealand. Christchurch: Canterbury University Press, 1993.

Sinclair, K. A Destiny Apart: New Zealand's Search for National Identity. Wellington: Unwin Paperbacks and Port Nicholson Press, 1986.

Smith, D., and G. Williams. Fields of Praise: The Official History of the Welsh Rugby Union, 1881-1981. Cardiff: University of Wales Press on behalf of the Welsh Rugby Union, 1980.

Swan, A.C. History of New Zealand Rugby Football 1870-1945. Wellington: Reed, 1948.

Swan, A.C. History of New Zealand Rugby Football Volume 2: 1946-1957. Wellington: New Zealand Rugby Football Union, 1958.

Thompson, R. Retreat from Apartheid: New Zealand's Sporting Contact with South Africa. Wellington: Oxford University Press, 1975.

Thompson, S. 'Challenging the Hegemony: New Zealand Women's Opposition to Rugby and the Reproduction of a Capitalist Patriarchy', International Review for the Sociology of Sport 23 (1988): 205-11.

Torres, C., and P. Hager. 'Competitive Sport, Evaluation Systems, and Just Results: The Case of Rugby Union's Bonus-Point System', Journal of the Philosophy of Sport 32 (2005): 208-22. 
Trelford, D. 'Brisbane Debacle due to Uncivil War', Electronic Telegraph, June 9, 1998.

Vamplew, W. Pay Up and Play Up the Game: Professional Sport in Britain 1875-1914. Cambridge: Cambridge University Press, 1988.

Vincent, G.T. 'Practical Imperialism: The Anglo-Welsh Rugby Tour of New Zealand', The International Journal of the History of Sport 15 (1998): 123-40.

Whitson, D. 'Circuits of Promotion: Media, Marketing and the Globalization of Sport'. In Mediasport, ed. L. A. Wenner. London: Routledge, 1998.

Whitson, D., and D. Macintosh. 'Rational Planning vs. Regional Interests: Professionalization of Canadian Sport'. Canadian Public Policy 15 (1989): 436-49.

Williams, G. 'How Amateur was My Valley: Professional Sport and National Identity in Wales 1890-1914'. British Journal of Sport History 2 (1985): 248-69.

Williams, G. 'Rugby Union'. In Sport in Britain. A Social History, ed. T. Mason. Cambridge: Cambridge University Press, 1989.

Zavos, S. Ka mate! Ka mate!: New Zealand's Conquest of British Rugby. Auckland: Viking, 1998. 